\title{
W poszukiwaniu strategii edukacyjnej przeciwdziałania wykluczeniu społecznemu osób z niepełnosprawnością
}

\begin{abstract}
Bąbka Jarosław, In search of an educational strategy for combating the social exclusion of disabled people [W poszukiwaniu strategii edukacyjnej przeciwdziałania wykluczeniu społecznemu osób z niepełnosprawnością]. Interdyscyplinarne Konteksty Pedagogiki Specjalnej, nr 4, Poznań 2014. Pp. 87-104. Adam Mickiewicz University Press. ISBN 978-83-232-2865-3. ISSN 2300-391X.
\end{abstract}

The paper attempts to search for arguments justifying an educational strategy aiming at preventing a social exclusion of the disabled by building social capital. The research review shows that people with some disabilities present a low level of social participation, which indicates a fragile nature of social capital among members of this group. Therefore, it was assumed that a significant form of preventing social exclusion can be education that aims at developing social skills and the ability to cooperate of the disabled. Activating the resources of social capital and benefiting from them requires from people to cooperate and act in a coordinated manner.

KEY WORDS: social capital, marginalization, disability, cooperation, exclusion.

\section{Wprowadzenie}

Marginalizacja i wykluczenie społeczne stanowią kategorie poznawcze, które pozwalają opisywać oraz wyjaśniać rzeczywistość grup defaworyzowanych, $\mathrm{w}$ tym osób $\mathrm{z}$ niepełnosprawnością. Przeciwieństwem marginalizacji tych ludzi jest ich partycypacja, uczest- 
nictwo w życiu społecznym¹ ${ }^{1}$ Coraz częściej podejmuje się próby ukazywania związku pomiędzy wykluczeniem a kapitałem społecznym. Taki kierunek myślenia zaprezentowano w opracowaniu. Celem artykułu jest przedstawienie argumentacji dotyczącej tego, że w przeciwdziałaniu wykluczeniu społecznemu powinno się uwzględniać strategie edukacyjne umożliwiające budowanie kapitału społecznego wśród uczniów z ograniczeniami sprawności. Nauka współpracy już w procesie edukacji osób z grup ryzyka wykluczenia społecznego sprzyja rozwijaniu społecznych kompetencji, których brak prowadzi do wypadania z naturalnych sieci społecznych, a ich posiadanie może przeciwdziałać temu zjawisku. Zdaniem Anny I. Brzezińskiej, Radosława Kaczana oraz Piotra Rycielskiego, „kompetencje społeczne zdobyte w naturalnych relacjach rodzinnych i sąsiedzkich oraz grupach rówieśniczych i towarzyskich stanowią ważny, w jakimś sensie podstawowy i «początkowy» kapitał osoby niepełnosprawnej [...]. Jest to jej swoisty [imput], umożliwiający lub ograniczający budowanie kolejnych relacji i związków społecznych"2.

\section{Marginalność, marginalizacja, wykluczenie - dyskusja pojęciowa}

Marginalność, marginalizacja, wykluczenie to pojęcia powiązane ze sobą. Marginalność dotyczy sytuacji niepełnej partycypacji jednostek lub grup w różnych dziedzinach życia. Marginalizacja odnosi się do ograniczania uczestnictwa jednostek albo grup w ży-

${ }^{1}$ R. Szarfenberg, Marginalizacja i wykluczenie społeczne - panorama językowo-teoretyczna, [w:] Ubóstwo i wykluczenie społeczne - perspektywa poznawcza, red. idem, C. Żołędowski, Dom Wydawniczy Elipsa, Warszawa 2010, s. 125.

2 A.I. Brzezińska, R. Kaczan, P. Rycielski, Układ czynników sprzyjajacych inkluzji i utrudniających inkluzję osób niepetnosprawnych, [w:] Wsparcie dla osób z ograniczeniami sprawności. Wyniki badań, red. tychże, Wydawnictwo Naukowe Scholar, Warszawa 2010, s. 58. 
ciu. Różnica pomiędzy marginalizacją a wykluczeniem (ekskluzją) wynika ze stopnia nasilenia zjawiska. Wykluczenie (ekskluzja) to „bardziej zaawansowana marginalizacja”3. Jolanta Grotowska-Leder uporządkowała różne definicje wykluczenia oraz wyróżniła trzy kategorie ujęć: analityczne, robocze (operacyjne) oraz oficjalne, wynikające $\mathrm{z}$ dokumentów ${ }^{4}$. W opracowaniu przyjęto definicję, w której akcentuje się różne przejawy marginalizacji, ograniczenia $\mathrm{w}$ uczestnictwie jednostek lub grup $\mathrm{w}$ rozmaitych obszarach życia społecznego, dostęp do zasobów i usług. Według Bronisława Urbana, marginalizacja to "pozostawienie pewnych jednostek poza głównym nurtem rozwoju społecznego, niemożliwość dostatecznego korzystania z ogólnego dorobku materialnego i kulturowego, pozbawienie lub ograniczenie udziału w jego pomnażaniu, co jest równoznaczne $\mathrm{z}$ zablokowaniem realizacji kształtowanych $\mathrm{w}$ ciągu okresu rozwojowego celów, aspiracji i pragnień"5. Za Leonem Dyczewskim ${ }^{6}$ można mówić o marginalizacji ekonomicznej, łączącej się z ograniczeniami na rynku pracy i konsumpcji, marginalizacji społecznej, która wiąże się z izolacją, marginalizacji politycznej, oznaczającej ograniczenia praw obywatelskich oraz wpływ na decyzje polityczne, marginalizacji kulturalnej, czyli utrudnionym dostępie do kultury i edukacji, marginalizacji informacyjno-medialnej, dotyczącej ograniczeń w dostępie do mediów oraz informacji, marginalizacji religijnej, związanej z wyłączeniem na tle religijnym, marginalizacji etnicznej, stanowiącej skutek przynależności do kultury mniejszości wobec kultury dominującej.

${ }^{3}$ A. Radziewicz-Winnicki, Pedagogika społeczna w obliczu realiów codzienności, Wydawnictwo Akademickie i Profesjonalne, Warszawa 2008, s. 252-253.

4 J. Grotowska-Leder, Ekskluzja społeczna - aspekty teoretyczne i metodologiczne, [w:] Ekskluzja i inkluzja społeczna. Diagnoza - uwarunkowania, kierunki działań, red. eadem, K. Faliszak, Wydawnictwo Edukacyjne Akapit, Torun 2005, s. 28-32.

${ }^{5}$ B. Urban, Geneza i psychospołeczne mechanizmy marginalizacji wspótczesnej mtodzieży polskiej, [w:] Zagadnienia marginalizacji $i$ patologizacji życia społecznego, red. F. Kozaczuk, Wydawnictwo Uniwersytetu Rzeszowskiego, Rzeszów 2005, s. 15.

${ }^{6}$ L. Dyczewski, Grupy marginalne, [w:] Kultura grup mniejszościowych i marginalizowanych, red. idem, Wydawnictwo KUL, Lublin 2005, s. 28. 
Wykluczenie społeczne wiąże się z mniejszym uczestnictwem w życiu społecznym w porównaniu z jego pozostałymi uczestnikami. O marginalności wnioskuje się na podstawie porównania sytuacji faktycznej z pewnym modelem - zbiorem ról, które jednostka lub grupa powinna odgrywać według przyjętych a priori zasad, idealnym modelem uczestnictwa7, jak i jakości życia jednostki albo grupy, oceny własnej sytuacji życiowej, w tym szans i ograniczeń ${ }^{8}$. Przyjęto, że bez względu na różne ujęcia marginalizacji jej konsekwencją jest ograniczone uczestnictwo jednostek w trzech obszarach życia społecznego: ekonomicznym, politycznym i społecznym.

Opisano wiele czynników sprzyjających wykluczeniu. Przyjmuje się, że marginalizacja i ekskluzja są wynikami ubóstwa materialnego, niedostatków kapitału społecznego, procesów towarzyszących globalizacji oraz przekształceniom gospodarczym, indywidualnych deficytów związanych z niskim poziomem wykształcenia, niedostatków rozwoju kapitału ludzkiego, a także chorób, niepełnosprawności, starości, dyskryminacji i przemocy ze strony silniejszych grup, braku odpowiedniej ochrony prawnej, socjalnej itp. ${ }^{9}$ Ekskluzja występuje częściej w społeczeństwach o słabo rozwiniętej sieci społecznej bądź w sytuacjach braku takich tradycji.

\section{Wybrane koncepcje marginalności i wykluczenia społecznego}

Wśród znaczących koncepcji marginalizacji wymienia się ujęcie Freda Mahlera. Autor ten nakreślił ogólny zbiór cech grupy marginalnej: pozbawienie władzy lub dostępu do podejmowania decyzji, mniejsze prawa, mniejsze możliwości wyboru, mniejsze zasoby

${ }^{7}$ G. Germani, za: R. Szarfenberg, op. cit., s. 109.

8 J. Kwaśniewski, Postrzeganie marginalizacji oraz strategii środków kontroli społecznej, [w:] Kontrola społeczna procesów marginalizacji, red. idem, Interart, Warszawa 1997, s. 197.

${ }^{9}$ A. Nowak, Zagrożenie wykluczeniem społecznym kobiet niepetnosprawnych, Wydawnictwo Uniwersytetu Śląskiego, Katowice 2012, s. 40. 
ekonomiczne, niższa pozycja ekonomiczna, gorsze możliwości edukacyjne i zawodowe, dyskryminacja prawna, społeczne naznaczenie oraz praktyki dyskryminacyjne. Powołuję się na tę koncepcję, ponieważ F. Mahler ujmuje marginalność w kontekście rozwoju osoby i jej partycypacji w szeroko rozumianym życiu społecznym. Ponadto $\mathrm{w}$ procesie analizy zjawiska marginalności przypisuje znaczenie procesom socjalizacji. Osoby marginalizowane mają ograniczoną podmiotowość, co wiąże się z ich uprzedmiotowieniem. Z kolei im większy poziom uprzedmiotowienia jednostki, tym mniejszy jej wpływ na życie własne i innych osób. Prawidłowy rozwój jednostki jest możliwy dzięki uczestnictwu w życiu społecznym. Sytuację osoby marginalnej charakteryzują: poczucie deprywacji i zagrożenia, frustracja, strach przed przyszłością, pesymizm, bierność, niezdolność do kierowania własnym życiem. Zdaniem F. Mahlera, marginalność trzeba ujmować $\mathrm{W}$ kontekście procesu socjalizacji, który może przebiegać dwojako: (1) jako proces wzmacniający postawy konformistyczne i adaptację do sytuacji marginalizacji lub (2) proces sprzyjający tendencjom emancypacyjnym nastawionym na wyzwolenie się i zmianę niekorzystnej sytuacji ${ }^{10}$.

Dla dalszych rozważań istotne jest drugie podejście. Oznacza ono, że marginalizacja nie powinna być uznawana za nieuniknioną oraz usprawiedliwiana. Z koncepcji Klausa Hurrelmanna ${ }^{11}$ wynika, że niepomyślny przebieg socjalizacji wymaga podejmowania interwencji, np. edukacyjnych, mających na celu rozwój kompetencji jednostek oraz zmiany w środowisku ich życia. Podejmowanie środków zaradczych odgrywa również rolę interwencji prewencyjnej, mającej na celu zapobieganie wykluczeniu różnych grup ryzyka.

Hilary Silver ${ }^{12}$ wyróżniła trzy paradygmaty społecznego wykluczenia: (1) solidarnościowy; (2) specjalizacji; (3) monopolizacji.

${ }^{10} \mathrm{~F}$. Mahler, za: I. Chrzanowska, Zaniedbane obszary edukacji - pomiędzy pedagogika a pedagogika specjalna. Wybrane zagadnienia, Oficyna Wydawnicza Impuls, Kraków 2009, s. 21-22.

11 K. Hurrelmann, Struktura społeczna a rozwój osobowości, Wydawnictwo Naukowe UAM, Poznań 1994, s. 155-167.

12 H. Silver, za: P. Broda-Wysocki, Wykluczenie i inkluzja społeczna. Paradygmaty i próby definicji, IPiSS, Warszawa 2012, s. 47-48. 
1. Wykluczenie $\mathrm{w}$ perspektywie solidarnościowej wiąże się z zerwaniem więzi społecznych pomiędzy jednostką a społeczeństwem. Grupa mająca określoną tożsamość broni się przed ludźmi, którzy nie spełniają kryteriów grupowych, co prowadzi do osłabiania się więzi emocjonalnych i tożsamościowych. W konsekwencji zanikają relacje pomiędzy społeczeństwem jako całością a poszczególnymi obywatelami. Paradygmat solidarnościowy nawiązuje do tradycji republikanizmu. W tym ujęciu państwo jako gwarant społecznej kohezji jest odpowiedzialne za tworzenie odpowiednich instytucji i polityki społecznej.

2. Wykluczenie w perspektywie specjalizacji jest wyjaśniane pod kątem postępującego zróżnicowania społecznego oraz podziału pracy. Przyczyn wykluczenia można się dopatrywać w relacjach między jednostkami o zróżnicowanych zdolnościach a wymianą rynkową obejmującą społeczeństwo. Ważne stają się umiejętności jednostek, sieci kontaktów, uczestnictwo w rynkach i stowarzyszeniach. Wykluczenie jest tożsame z dyskryminacją. Oznacza ograniczony dostęp jednostek do społecznej wymiany, zasobów, działań. W paradygmacie specjalizacji, który nawiązuje do tradycji liberalizmu, rola państwa sprowadza się do poprawy kondycji jednostek, wzmocnienia poczucia ich podmiotowości oraz opracowania takiego wzoru obywatelskości, z którego wynikałyby prawa i obowiązki jednostki.

3. Według paradygmatu monopolizacji, wykluczenie społeczne ma źródło w hierarchii społecznej. Grupy uprzywilejowane mają większe wpływy, ograniczają innym dostęp do zasobów i ich dystrybuowanie - dążą tym samym do utrzymywania nierówności społecznych. Ekskluzja dokonuje się poprzez praktyki monopolizacyjne, które sprzyjają ochronie zasobów posiadanych przez grupy uprzywilejowane. Paradygmat monopolizacji wywodzi się z tradycji socjaldemokracji. Rola państwa sprowadza się do wyrównoważenia sił grup dominujących, kompensowania sytuacji nierówności poprzez zabezpieczenia socjalne oraz formułowania praw indywidualnych i wspólnotowych. 
Opisane paradygmaty świadczą o tym, że różnice w podejściu do wykluczenia społecznego zależą od kontekstu kulturowego oraz ekonomicznego, tradycji politycznych i socjologicznych.

\section{Społeczne wykluczenie osób z niepełnosprawnością w świetle wybranych wyników badań}

Osoby z niepełnosprawnością są zaliczane do kategorii zagrożonej marginalizacją i wykluczeniem społecznym. Można wyróżnić co najmniej trzy podstawowe obszary badawcze związane ze zjawiskiem wykluczenia i inkluzji osób z ograniczeniami sprawności: (1) przejawy wykluczenia/inkluzji; (2) uwarunkowania procesu wykluczenia/inkluzji; (3) konsekwencje wykluczenia/inkluzji ${ }^{13}$. Opracowanie nie ma na celu analizy rozproszonych pod tym względem wyników badań. Bardziej zasadne jest ukazanie zjawiska marginalizacji oraz wykluczenia społecznego osób z różnymi rodzajami niepełnosprawności w początkowym okresie transformacji ustrojowej i czasach obecnych.

Z długofalowych badań Antoniny Ostrowskiej i Janiny Sikorskiej ${ }^{14}$ wynika, że w latach 90. proces marginalizacji rzadko przybierał formy ekstremalne. Dzięki zabezpieczeniom społecznym niepełnosprawni nie doświadczali nędzy. Znajdowali się jednak w niekorzystnej sytuacji w kwestiach odgrywania ról społecznych, samorealizacji czy relacji z resztą społeczeństwa. Kontynuowane przez autorki badania pod koniec dekady pozwoliły określić następujące typy sytuacji życiowych osób z niepełnosprawnością: aktywność życiowa, pasywność, wyizolowanie, upośledzenie statusowe. Wśród czynników wyjaśniających wymienia się: niskie wykształcenie, za-

13 A.I. Brzezińska, R. Kaczan, P. Rycielski, Obszary i modele badań nad zjawiskami wykluczania i inkluzji osób z ograniczeniami sprawności, „Polityka Społeczna”, 2010, numer specjalny (Diagnoza potrzeb i podstawy interwencji społecznych na rzecz osób z ograniczeniami sprawności), s. 58-62.

14 A. Ostrowska, J. Sikorska, Syndrom niepetnosprawności w Polsce. Bariery integracji, IFiS PAN, Warszawa 1996, s. 153-198. 
mieszkiwanie na wsi oraz starszy wiek respondentów. Z badań wynika, że zakres kontaktów społecznych nie był szeroki. Relacje ograniczały się do kontaktów z rodziną i osobami z najbliższego otoczenia, a także do uczestnictwa w praktykach religijnych. Sami niepełnosprawni deklarowali gotowość do kontaktów społecznych z pełnosprawnymi. Odnotowano zmiany świadczące o otwieraniu się naszego społeczeństwa na niepełnosprawnych. Wzrósł odsetek osób znających niepełnosprawnych osobiście (z 34\% do 43\%) oraz dostrzegających ich $\mathrm{w}$ najbliższym otoczeniu (z 40\% do 68\%). Powiększyła się również grupa osób opowiadających się za integracyjnymi rozwiązaniami w sferze pracy i zatrudnienia (o 7\%). Autorki dostrzegły zmniejszającą się gotowość respondentów do pomocy sąsiedzkiej osobom z niepełnosprawnością (z 77\% do 69\%). Jednymi z ważniejszych czynników przeciwdziałających marginalizacji okazały się aktywność społeczna niepełnosprawnych, znajomość przepisów ułatwiających korzystanie z przysługujących uprawnień oraz wpływ na sytuację innych osób z niepełnosprawnością. Niestety, badani rzadko angażowali się w działalność organizacji społecznych, tj. zawodowych, politycznych, kościelnych czy też zrzeszających niepełnosprawnych. Słabo orientowali się w przysługujących im prawach oraz przywilejach. Zdaniem autorek, osoby z niepełnosprawnością "przegrywają w konkurencji z innymi grupami, jakie pretendują do świadczeń"15.

Zmiany dotyczące gospodarki, polityki społecznej państwa oraz demokratyzacji różnych dziedzin życia spowodowały, że Dorota Wiszejko-Wierzbicka skoncentrowała się w najnowszych badaniach na partycypacji społecznej i obywatelskiej osób z niepełnosprawnością, rozumianej jako uczestnictwo w różnych sferach życia społecznego, takich jak np. rodzina, rekreacja, aktywność w życiu społeczności lokalnej. Rozwój społeczeństwa obywatelskiego stanowi ważny aspekt demokratyzacji. Społeczeństwo obywatelskie daje niepełnosprawnym jako grupie marginalizowanej szansę udziału

15 Także: B. Gąciarz, Osoby niepetnosprawne w Polsce w latach dziewięćdziesiątych, ISP, Warszawa 2001, s. 148-151, 177. 
w organizacjach i stowarzyszeniach, a także wpływania na środowisko ich życia. Wolność, partnerstwo, odpowiedzialność są trudne do realizacji przez niepełnosprawnych. Według D. Wiszejko-Wierzbickiej16, realizowana przez dziesięciolecia polityka społeczna wzmacniała bierność niepełnosprawnych oraz nie prowadziła do kształtowania postaw obywatelskich, rozwoju umiejętności współpracy i solidarności w rozwiązywaniu problemów społecznych. Zjawisko to jest połączone $\mathrm{z}$ ogólnopolską tendencją do spadku liczby osób działających w organizacjach społecznych oraz zanikiem demokracji partycypacyjnej, polegającej na uwzględnianiu interesów różnych mniejszości. Z badań wynika, że niska aktywność społeczna i obywatelska dotyczy osób znajdujących się w najgorszym położeniu społecznym oraz materialnym ${ }^{17}$. Ludzie z ograniczoną sprawnością poświęcają najwięcej uwagi rodzinie i bliskim relacjom, a w dalszej kolejności - pracy i nauce. Na kolejnych miejscach plasowały się wypoczynek i rekreacja oraz aktywność społeczna i obywatelska (ok. 8\%). Osoby z niepełnosprawnością nie dążą do większych zmian w życiu. Istnieją bariery psychologiczne, społeczne oraz strukturalne, które ograniczają ich aktywność społeczną i obywatelską. Niska samoocena, brak przygotowania do tego rodzaju aktywności, nawyki ukształtowane w procesie edukacji i w rodzinie, postawa roszczeniowa to niektóre ograniczenia psychologiczne, które sprzyjają tendencjom izolacyjnym wśród niepełnosprawnych oraz nienawiązywaniu przez nich kontaktów z otoczeniem. Wśród barier społecznych wymienia się negatywne postawy wobec niepełnosprawnych oraz niską wiedzę społeczeństwa na temat niepełnosprawności. Osoby z ograniczoną sprawnością wykazują słabą znajomość organizacji działających na rzecz niepełnosprawnych.

16 D. Wiszejko-Wierzbicka, Niewykorzystana sfera. Partycypacja społeczna i obywatelska osób z ograniczeniami sprawności, Wydawnictwo Naukowe Scholar, Warszawa 2010, s. 51-77.

17 B. Wciórka, Grupowa aktywność społeczna Polaków w latach 1998-2004. Komunikat z badań, Centrum Badania Opinii Społecznej, Warszawa 2004, http://www.cbos.pl [dostęp: 15.05.2014]; D. Wiszejko-Wierzbicka, op. cit., s. 12-15, 23. 
Przedstawione wyniki badań świadczą o tym, że wiedza społeczeństwa o niepełnosprawnych jest ciągle zbyt mała, a utrzymujące się negatywne postawy wobec tej kategorii ludzi sprzyjają tendencjom izolacyjnym i marginalizującym. Konkurencyjność jako cnota neoliberalizmu charakteryzująca obecne czasy wymusza wśród ludzi zachowania rywalizacyjne, osłabia zaufanie, solidarność międzyludzką oraz zachowania prospołeczne ${ }^{18}$. Przedstawione badania dowodzą „kruchości kapitału społecznego" oraz braku inicjatywy dla samodzielnego rozwiązywania problemów przez niepełnosprawnych. W związku z tym pojawiają się oczekiwania wobec szkoły i edukacji, które powinny przygotować wychowanków do podejmowania aktywności społecznej oraz obywatelskiej ${ }^{19}$. Istnieje potrzeba edukacji na rzecz tworzenia warunków umożliwiających społeczną inkluzję osób z niepełnosprawnością poprzez naukę właściwego reagowania na własne ograniczenia psychofizyczne oraz rozwijanie kompetencji społecznych sprzyjających nawiązywaniu kontaktów międzyludzkich, ukazywanie znaczenia współistnienia i współpracy, a także przeciwdziałanie biernej i wycofanej postawie życiowej.

\section{Budowanie kapitału społecznego jako strategia przeciwdziałania wykluczeniu społecznemu osób z niepełnosprawnością}

Podejmowane są próby ukazania związku pomiędzy wykluczeniem społecznym a kapitałem społecznym ${ }^{20}$. Ponadto $\mathrm{w}$ polityce społecznej podkreśla się znaczenie budowania kapitału społecznego dla przeciwdziałania społecznej ekskluzji grup defaworyzowanych.

18 E. Potulicka, Wolny rynek edukacyjny a zagrożenia dla demokracji, [w:] Neoliberalne uwikłania edukacji, red. eadem, J. Rutkowiak, Oficyna Wydawnicza Impuls, Kraków 2012, s. 108-109.

${ }^{19}$ D. Wiszejko-Wierzbicka, op. cit., s. 51-62, 75.

20 Utopie inkluzji. Sukcesy i porażki programów reintegracji społecznej, red. K.W. Frieske, Instytut Pracy i Spraw Socjalnych, Warszawa 2004. 
Według Jamesa Colemana, kapitał społeczny ${ }^{21}$ to przede wszystkim „umiejętność współpracy międzyludzkiej w obrębie grup i organizacji w celu realizacji wspólnych interesów" 22 . Robert D. Putnam ${ }^{23}$ definiuje kapitał społeczny w kontekście cech organizacji społeczeństwa, takich jak zaufanie, normy i powiązania, które mogą sprzyjać koordynacji działań. Zasadniczą formę społecznego kapitału stanowią sieci obywatelskiego zaangażowania. Im są one gęstsze, tym większe prawdopodobieństwo współpracy ludzi. Sieci te sprzyjają powstawaniu norm wzajemności oraz społecznemu zaufaniu, umożliwiają komunikację i przepływ informacji, stanowią wzór przyszłej udanej współpracy. Według Marii Theiss, można wyróżnić trzy stanowiska dotyczące związku pomiędzy wykluczeniem społecznym a kapitałem społecznym ${ }^{24}$. Pierwsze polega na traktowaniu kategorii jako odrębnych, wywodzących się z odległych sobie nurtów społecznych. Chodzi np. o to, że badanie wykluczenia społecznego wiąże się z analizą makrospołeczną oraz systemowymi mechanizmami ekskluzji. Z kolei badanie kapitału społecznego pociąga za sobą analizę mikrospołeczną. Kapitał społeczny jest cechą kultury lokalnej lub regionalnej. Przyjmuje się też, że dysponentami kapitału społecznego stają się jednostki i małe grupy społeczne. Te różnice znajdują wyraz $\mathrm{w}$ odmiennych koncepcjach zmiany społecznej. Kapitał społeczny to zasób, który powstaje oddolnie. Działania dla rozwoju lokalnego polegają na zwiększaniu samoorganizacji i budowaniu sieci współpracy $\mathrm{w}$ środowisku lokalnym.

${ }^{21}$ Szerzej na temat kapitału społecznego: J. Bąbka, Przygotowanie uczniów z niepetnosprawnościa i petnosprawnych do wspótpracy jako wyzwanie dla wspótczesnej edukacji, [w:] Miejsce Innego we wspótczesnych naukach o wychowaniu, red. B. Jachimczak, K. Pawelczak, A. Wojciechowska, Wydawnictwo Naukowe UAM, Poznań 2014, s. $25-40$.

22 J. Coleman, za: M. Kwiatkowski, M. Theiss, Kapitat spoteczny. Od metafory do badań, „Rocznik Lubuski”, 2004, t. XXX, s. 15.

${ }^{23}$ R.D. Putnam, Demokracja w działaniu. Tradycje obywatelskie we wspótczesnych Wtoszech, Wydawnictwo Znak, Kraków 1995, s. 258, 270-271.

${ }^{24} \mathrm{M}$. Theiss, Kapitał społeczny a wykluczenie społeczne, [w:] Ubóstwo i wykluczenie spoteczne - perspektywa poznawcza, ed. cit., s. 144. 
Zmiany społeczne wynikające z koncentracji na ekskluzji i inkluzji społecznej przyjmują formy programów na rzecz upodmiotowienia grup marginalizowanych, oddolnych głosów mających wpływ na decyzje polityczne.

Z drugiego stanowiska wynika, że kapitał społeczny zawiera się w koncepcji wykluczenia społecznego. Oznacza to, że jego niskie zasoby są możliwym, ale niekoniecznym składnikiem wykluczenia społecznego grup i osób. Takie podejście pozwala ujmować wykluczenie społeczne $\mathrm{w}$ kategorii wielowymiarowego ubóstwa, niedostatku możliwości oraz braku partycypacji w różnych sferach życia społecznego. Ubóstwo dotyczące kapitału społecznego wyraża się $\mathrm{w}$ braku dostępu do szerokich sieci społecznych w odróżnieniu od powiązań jednostki z rodziną. Wykluczenie jako niski poziom partycypacji społecznych przejawia się zarówno w braku znajomych, jak i w ograniczonym udziale jednostki lub grupy $\mathrm{w}$ produkcji, konsumpcji, kulturze, wypoczynku, a także życiu politycznym (udział $\mathrm{w}$ wyborach itp.). Istnieją dowody na współwystępowanie niskiego kapitału społecznego $\mathrm{z}$ wykluczeniem $\mathrm{w}$ różnych sferach życia ${ }^{25}$.

Zgodnie z trzecim stanowiskiem, kapitał społeczny i wykluczenie społeczne to kategorie, które się przecinają. Niski kapitał społeczny może być elementem wykluczenia społecznego. Sens kapitału społecznego znacznie wykracza poza przeciwieństwo społecznej izolacji, utożsamianej z wykluczeniem. W ujmowaniu kapitału społecznego ważna jest nie tylko skala kontaktów społecznych, tj. liczba osób, z którymi ktoś utrzymuje kontakty, lecz także charakterystyka relacji społecznych, stwarzających różne możliwości działania. M. Theiss uważa, że odwoływanie się do koncepcji kapitału społecznego może dostarczać polityce społecznej koncepcji działań na

${ }^{25}$ Istnieją związki pomiędzy różnymi typami wykluczenia (np. fizycznego, normatywnego, materialnego) a kontaktami towarzyskimi, pomiędzy kapitałem społecznym wyrażającym się w udziale w wyborach, w życiu społeczności lokalnej a wykluczeniem społecznym. Zob. J. Czapiński, Rodzaje wykluczenia społecznego, [w:] Diagnoza spoteczna 2009. Warunki i jakość życia Polaków, red. idem, T. Panek, Rada Monitoringu Społecznego, WSFiZ w Warszawie, Warszawa 2009, s. 342-343. 
rzecz walki z problemem wykluczenia. Szczególną rolę $\mathrm{w}$ teorii kapitału społecznego odgrywają tzw. powiązania pomostowe, tj. słabe ze względu na częstotliwość, niehierarchiczne oraz łączące osoby o różnych charakterystykach społeczno-ekonomicznych.

Wyróżnia się trzy stanowiska, z których wynikają rozmaite strategie działań przeciwdziałania wykluczeniu społecznemu: (1) defetystyczne; (2) upodmiotowiające; (3) komunitariańskie. Podejście defetystyczne polega na tym, że więzi społeczne osób marginalizowanych przyczyniają się do podtrzymywania i utrwalania zjawiska wykluczenia społecznego. Stanowisko to może być uzasadnieniem dla zaniechania działań przeciwdziałających marginalizacji i wykluczeniu. Strategia upodmiotowienia zakłada wzmacnianie więzi w obrębie grup ludzi podobnych do siebie. W kontekście wykorzystania teorii kapitału społecznego dla przeciwdziałania zjawisku społecznego wykluczenia znaczenia nabiera podejście komunitariańskie. W tym ujęciu podkreśla się znaczenie relacji międzyludzkich, będących podstawą budowania kapitału pomostowego w środowisku lokalnym ${ }^{26}$.

Z przedstawionych ujęć wynikają nieco inne kierunki przeciwdziałania wykluczeniu społecznemu. Mogą one wiązać się z odgórnymi działaniami na wyższych szczeblach politycznego decydowania $w$ zakresie usuwania barier w dostępie do pracy i edukacji czy walki z ubóstwem, mieć charakter programów upodmiotowienia. Zgodnie $z$ ideą niniejszego opracowania, szans na przeciwdziałanie wykluczeniu społecznemu osób z ograniczeniami sprawności można dopatrywać się w więziach międzyludzkich, postawach, rozwijaniu społecznych kompetencji u przedstawicieli grup ryzyka oraz budowaniu sieci współpracy we wspólnotach lokalnych. Wynika z tego, że w trakcie poszukiwań czynników sprzyjających społecznej inkluzji grup marginalizowanych warto się skoncentrować na strukturze i kulturze społeczności, w których są one zlokalizowane. Takie podejście nawiązuje do trzeciego stanowiska na temat relacji

${ }^{26} \mathrm{~W}$ Polsce realizacja takich działań znajduje uzasadnienie w Strategii wspierania rozwoju społeczeństwa obywatelskiego na lata 2009-2015. 
wykluczenie - kapitał społeczny oraz podejścia komunitariańskiego. Kapitał społeczny ułatwia współpracę i skoordynowane działania, a także realizację zbiorowych przedsięwzięć. M. Theiss słusznie zauważa, że idea „zintegrowanej i obywatelskiej wspólnoty lokalnej" jawi się jako nierealistyczna i utopijna, ale zyskuje dużą popularność w polityce społecznej27.

\section{Budowanie w szkole kapitału społecznego poprzez przygotowanie uczniów z niepełnosprawnością do współpracy}

W opracowaniu przyjęto, że edukacja, w której trakcie przygotowuje się wychowanków z niepełnosprawnością do współpracy, przyczynia się do rozwijania umiejętności budowania sieci społecznych $^{28}$. Wyróżnione przez Paula Bullena i Jenny Onyx ${ }^{29}$ wyznaczniki kapitału społecznego, takie jak: działanie $w$ ramach sieci, wzajemność, zaufanie, normy społeczne, wspólnota, postawa aktywna, zaangażowanie się ludzi we wspólne działanie, towarzyszą współpracy. Maria Dudzikowa przekonuje o konieczności położenia większego nacisku $\mathrm{w}$ procesie wychowania na kwestie związane z kapitałem społecznym: „Jeszcze nigdy nie byliśmy w takiej sytuacji, kiedy to właśnie pytanie o kapitał społeczny i perspektywy jego rozwoju w środowisku szkolnym miało tak wielką rangę jak obecnie"30. Badania dowodzą małych szkolnych zasobów kapitału społecznego w wymiarze społecznego zaangażowania wychowanków. Współczesna szkoła nie stwarza możliwości aktywności w sferze

${ }^{27}$ M. Theiss, Kapitat spoteczny..., ed. cit., s. 144.

28 Szerzej na ten temat: J. Bąbka, op. cit.

${ }^{29}$ P. Bullen, J. Onyx, za: W. Dyduch, Sktadniki i wymiary kapitatu społecznego organizacji, „Organizacja i Kierowanie”, 2004, nr 1, s. 47-49.

${ }^{30}$ M. Dudzikowa, Erozja kapitału społecznego w szkole w atmosferze nieufności, [w:] Kapitał społeczny w szkołach różnego szczebla. Diagnoza i uwarunkowania, red. eadem, S. Jaskulska, R. Wawrzyniak-Beszterda, E. Bochno, I. Bochno, K. Knasiecka-Falbierska, M. Marciniak, t. II, Oficyna Wydawnicza Impuls, Kraków 2011, s. 42. 
publicznej, swobodnego wyrażania własnych opinii na łamach mediów szkolnych czy praktycznego uczestniczenia w nauce współrządzenia, demokracji, współdziałania społecznego oraz współodpowiedzialności. Uczniowie doświadczają presji rywalizacji i indywidualnego sukcesu ${ }^{31}$. Niepełnosprawna młodzież nie dysponuje doświadczeniem uczestnictwa we współdziałaniu, które stwarzałoby szansę upodmiotowienia $\mathrm{w}$ przestrzeni szkolnej, a następnie lokalnej ${ }^{32}$. Kapitał społeczny z jednej strony jest zapisany w kulturze grupy, z drugiej zaś może być powiększany poprzez umiejętne inwestowanie $\mathrm{w}$ ludzi. Wiąże się $\mathrm{z}$ kapitałem ludzkim, traktowanym jako zasób zdrowia pojedynczych ludzi, skumulowana wiedza, kompetencje, zdolności do podejmowania działań i rozwiązywania różnych problemów, w tym również umiejętność wspólpracy33. Według Anety A. Wiktorzak, budowanie kapitału ludzkiego „obejmuje zmiany w umiejętnościach i zdolnościach, natomiast kapitał społeczny powstaje, gdy stosunki międzyludzkie ulegają zmianie w sposób ułatwiający współpracę i współdziałanie"34. Budowanie w szkole kapitału społecznego polega na zidentyfikowaniu jego składników, czyli tego, co tkwi w ludziach - kapitału ludzkiego (wiedzy, umiejętności), a także oddziaływaniu na to, co ma wpływ na ich działania, np. gotowość do współpracy. Wynika

${ }^{31}$ Eadem, Ku sprawstwu, wspótpracy i refleksyjności poprzez ich doświadczanie w edukacji szkolnej. Brunerowskie przestanie w praktyce, [w:] Doświadczenia szkolne pierwszego rocznika edukacji, red. eadem, R. Wawrzyniak-Beszterda, Oficyna Wydawnicza Impuls, Kraków 2011, s. 337-413.

${ }_{32} \mathrm{~J}$. Bąbka, Zachowania kooperacyjne w sytuacjach zadaniowych u mtodzieży w okresie wczesnej adolescencji. Analiza porównawcza młodzieży petnosprawnej i z różnymi ograniczeniami sprawności, Oficyna Uniwersytetu Zielonogórskiego, Zielona Góra 2012, s. 244-245, 254.

${ }^{33}$ S. Walukiewicz, Kapitał ludzki i społeczny jako przedmiot badań pedagogicznych, [w:] Badania międzynarodowe i wzory zagraniczne w diagnostyce edukacyjnej: XV Krajowa Konferencja Diagnostyki Edukacyjnej, Kielce 4-6 grudnia 2009 r., red. B. Niemierko, M.K. Szmigiel, Grupa Tomami, Kraków 2009, s. 97-98.

${ }^{34}$ E.A. Wiktorzak, Kapitat spoteczny szkoty, [w:] Badania międzynarodowe i wzory zagraniczne w diagnostyce edukacyjnej: XV Krajowa Konferencja Diagnostyki Edukacyjnej, Kielce 4-6 grudnia 2009 r., ed. cit., s. 258. 
z tego, że budowanie pozytywnego kapitału społecznego polega na rozwijaniu relacji mających u podstaw zaufanie, współpracę, otwartość itp.

\section{Konkluzja}

Przedstawione wyniki badań potwierdziły kruchość kapitału społecznego wśród osób z ograniczeniami sprawności. Idea budowania kapitału społecznego stanowi przykład strategii edukacyjnej mającej na celu przeciwdziałanie wykluczeniu społecznemu osób z niepełnosprawnością. To tylko zarys strategii edukacyjnej, w której wykorzystuje się budowanie kapitału społecznego poprzez naukę współpracy osób niepełnosprawnych. Wymagane są dalsze poszukiwania, umożliwiające przedstawienie idei $\mathrm{w}$ działaniu. Koncentracja na współpracy wynika z ustaleń A.I. Brzezińskiej z zespołem o pierwszoplanowej roli kontaktów społecznych dla społecznej inkluzji ludzi marginalizowanych. Badacze uważają, że do czynników przeciwdziałających wykluczaniu i ułatwiających inkluzję należą m.in. zakres i jakość sieci społecznych (rodzinnych, sąsiedzkich, przyjacielskich). Oznacza to, że zarówno w kształceniu segregacyjnym, integracyjnym, jak i inkluzyjnym warto uwzględniać programy edukacyjne rozwijające $u$ niepełnosprawnych wychowanków umiejętności budowania sieci społecznych dzięki modyfikowaniu codziennych interakcji, co przypomina rodzaj interwencji prewencyjnej. „Taki model edukacji poza walorami proinkluzyjnymi przyczynia się do tworzenia naturalnych sieci wsparcia, które powstają podczas wspólnych działań"35. Edukacja przygotowująca do współpracy stanowi część posiadanego kapitału społecznego jednostki oraz zestaw cech i umiejętności, które ułatwiają życie w społeczeństwie ${ }^{36}$.

35 A.I. Brzezińska, R. Kaczan, P. Rycielski, Układ czynników..., ed. cit., s. 62, 89.

36 Ibidem, s. 79, 89. 


\section{Bibliografia}

BĄBKA J., Przygotowanie uczniów z niepetnosprawnością i petnosprawnych do wspótpracy jako wyzwanie dla wspótczesnej edukacji, [w:] Miejsce Innego we wspótczesnych naukach o wychowaniu, red. B. Jachimczak, K. Pawelczak, A. Wojciechowska, Wydawnictwo Naukowe UAM, Poznań 2014.

BĄBKA J., Zachowania kooperacyjne w sytuacjach zadaniowych u mtodzieży w okresie wczesnej adolescencji. Analiza porównawcza młodzieży petnosprawnej i z różnymi ograniczeniami sprawności, Oficyna Uniwersytetu Zielonogórskiego, Zielona Góra 2012.

BRODA-WYSOCKI P., Wykluczenie i inkluzja spoteczna. Paradygmaty i próby definicji, IPiSS, Warszawa 2012.

BRZEZIŃSKA A.I., KACZAN R., RYCIELSKI P., Obszary $i$ modele badań nad zjawiskami wykluczania $i$ inkluzji osób z ograniczeniami sprawności, „Polityka Społeczna”, 2010, nr specjalny: Diagnoza potrzeb i podstawy interwencji społecznych na rzecz osób z ograniczeniami sprawności.

BRZEZIŃSKA A.I., KACZAN R., RYCIELSKI P., Układ czynników sprzyjających inkluzji i utrudniających inkluzje osób niepetnosprawnych, [w:] Wsparcie dla osób z ograniczeniami sprawności. Wyniki badań, red. tychże, Wydawnictwo Naukowe Scholar, Warszawa 2010.

CHRZANOWSKA I., Zaniedbane obszary edukacji - pomiędzy pedagogika a pedagogikg specjalna. Wybrane zagadnienia, Oficyna Wydawnicza Impuls, Kraków 2009.

CZAPIŃSKI J., Rodzaje wykluczenia społecznego, [w:] Diagnoza społeczna 2009. Warunki i jakość życia Polaków, red. idem, T. Panek, Rada Monitoringu Społecznego, WSFiZ w Warszawie, Warszawa 2009.

DUDZIKOWA M., Ku sprawstwu, wspótpracy i refleksyjności poprzez ich doświadczanie w edukacji szkolnej. Brunerowskie przestanie w praktyce, [w:] Doświadczenia szkolne pierwszego rocznika edukacji, red. eadem, R. Wawrzyniak-Beszterda, Oficyna Wydawnicza Impuls, Kraków 2011.

DYCZEWSKI L., Grupy marginalne, [w:] Kultura grup mniejszościowych i marginalizowanych, red. idem, Wydawnictwo KUL, Lublin 2005.

DYDUCH W., Składniki i wymiary kapitatu społecznego organizacji, „Organizacja i Kierowanie", 2004, nr 1.

GROTOWSKA-LEDER J., Ekskluzja społeczna - aspekty teoretyczne i metodologiczne, [w:] Ekskluzja i inkluzja społeczna. Diagnoza - uwarunkowania, kierunki działan, red. eadem, K. Faliszak, Wydawnictwo Edukacyjne Akapit, Toruń 2005.

GROWIEC K., Kapitał spoteczny. Geneza i społeczne konsekwencje, Wydawnictwo Szkoły Wyższej Psychologii Społecznej Academica, Warszawa 2011.

HURRELMANN K., Struktura spoteczna a rozwój osobowości, Wydawnictwo Naukowe UAM, Poznań 1994. 
KWAŚNIEWSKI J., Postrzeganie marginalizacji oraz strategii środków kontroli spotecznej, [w:] Kontrola społeczna procesów marginalizacji, red. idem, Interart, Warszawa 1997.

KWIATKOWSKI M., THEISS M., Kapitat społeczny. Od metafory do badań, „Rocznik Lubuski", 2004, t. XXX.

NOWAK A., Zagrożenie wykluczeniem spotecznym kobiet niepetnosprawnych, Wydawnictwo Uniwersytetu Śląskiego, Katowice 2012.

OSTROWSKA A., SIKORSKA J., Syndrom niepetnosprawności w Polsce. Bariery integracji, IFiS PAN, Warszawa 1996.

OstrowSKA A., SIKORSKA J., GĄCIARZ B., Osoby niepetnosprawne w Polsce w latach dziewięćdziesiatych, ISP, Warszawa 2001.

POTULICKA E., Wolny rynek edukacyjny a zagrożenia dla demokracji, [w:] Neoliberalne uwiktania edukacji, red. eadem, J. Rutkowiak, Oficyna Wydawnicza Impuls, Kraków 2012.

PUTNAM R.D., Demokracja w działaniu. Tradycje obywatelskie we wspótczesnych Włoszech, Wydawnictwo Znak, Kraków 1995.

RaDZIEWICZ-WinNicKI A., Pedagogika społeczna w obliczu realiów codzienności, Wydawnictwo Akademickie i Profesjonalne, Warszawa 2008.

Strategia wspierania rozwoju społeczeństwa obywatelskiego na lata 2009-2015.

SZARFENBERG R., Marginalizacja i wykluczenie spoteczne - panorama jezykowo-teoretyczna, [w:] Ubóstwo i wykluczenie społeczne - perspektywa poznawcza, red. idem, C. Żołędowski, Dom Wydawniczy Elipsa, Warszawa 2010.

THEISS M., Kapitał spoteczny a wykluczenie społeczne, [w:] Ubóstwo i wykluczenie spoteczne - perspektywa poznawcza, red. R. Szarfenberg, C. Żołędowski, Dom Wydawniczy Elipsa, Warszawa 2010.

URBAN B., Geneza i psychospołeczne mechanizmy marginalizacji wspótczesnej młodzieży polskiej, [w:] Zagadnienia marginalizacji i patologizacji życia społecznego, red. F. Kozaczuk, Wydawnictwo Uniwersytetu Rzeszowskiego, Rzeszów 2005.

WALUKIEWICZ S., Kapitat ludzki i społeczny jako przedmiot badań pedagogicznych, [w:] Badania międzynarodowe i wzory zagraniczne w diagnostyce edukacyjnej: XV Krajowa Konferencja Diagnostyki Edukacyjnej, Kielce 4-6 grudnia 2009 r., red. B. Niemierko, M.K. Szmigiel, Grupa Tomami, Kraków 2009.

WCiÓRKA B., Grupowa aktywność społeczna Polaków w latach 1998-2004. Komunikat $z$ badań, Centrum Badania Opinii Społecznej, Warszawa 2004, http:/ /www.cbos.pl [dostęp: 15.05.2014].

WIKTORZAK E., Kapitał spoteczny szkoty, [w:] Badania międzynarodowe i wzory zagraniczne w diagnostyce edukacyjnej: XV Krajowa Konferencja Diagnostyki Edukacyjnej, Kielce 4-6 grudnia 2009 r., red. B. Niemierko, M.K. Szmigiel, Grupa Tomami, Kraków 2009.

WISZEJKO-WIERZBICKA D., Niewykorzystana sfera. Partycypacja spoteczna i obywatelska osób z ograniczeniami sprawności, Wydawnictwo Naukowe Scholar, Warszawa 2010. 